Original Research Paper

\title{
Larvicidal Activity of Bruceine A against Aedes aegypti and Toxicity on Vero Cells
}

\author{
${ }^{1}$ Dwi Sutiningsih, ${ }^{2}$ Mustofa, ${ }^{3}$ Tri Baskoro Tunggul Satoto and ${ }^{4}$ Edhi Martono \\ ${ }^{I}$ Department of Epidemiology and Tropical Disease, \\ Faculty of Public Health, Diponegoro University, Semarang, Indonesia \\ ${ }^{2}$ Department of Pharmacology, Faculty of Medicine, Gadjah Mada University, Yogyakarta, Indonesia \\ ${ }^{3}$ Department of Parasitology, Faculty of Medicine, Gadjah Mada University, Semarang, Indonesia \\ ${ }^{4}$ Department of Plant Pest and Diseases, Faculty of Agriculture, Gadjah Mada University, Yogyakarta, Indonesia
}

Article history

Received: 16-05-2018

Revised: $16-08-2018$

Accepted: 31-08-2018

\section{Corresponding Author:}

Dwi Sutiningsih

Department of Epidemiology

and Tropical Disease, Faculty

of Public Health, Diponegoro

University, Semarang,

Indonesia

Email:

dwi.sutiningsih@live.undip.ac.id

\begin{abstract}
Vector control is still based on the use of chemical insecticides, which can cause death of nontarget animals, pollution and the emergence of vector resistance. This study aims to assess the larvicidal activity of bruceine A against larvae of Aedes aegypti and its cytotoxic activity against Vero cells. Extraction and isolation of bruceine A from the seeds of Brucea javanica (L.) Merr by method of Subeki. The purity of bruceine A isolate is determined by using a thin layer of chromatography and high performance liquid chromatography. Larvicidal activity of bruceine A on the larvae of $A$. aegypti from instar III until the beginning of instar IV was measured using a bioassay method. The examination of bruceine A cytotoxicity on Vero cells was performed by Micro-culture Tetrazolium assay (MTT). The results showed that mortality of $A$. aegypti larvae increased with increasing concentration of bruceine A. Log probit analysis of the larva mortality showed that the lethal concentration 50 and $90\left(\mathrm{LC}_{50}, \mathrm{LC}_{90}\right)$ were $0.453 \pm 0.022 \mathrm{ppm}$ and $4.962 \pm 0.681 \mathrm{ppm}$ for $24 \mathrm{~h}$ respectively. The cytotoxic activity of bruceine A in Vero cells is low, with inhibitor concentration $50 \quad\left(\mathrm{IC}_{50}\right)$ values of $1251.324 \pm 0.162 \mu \mathrm{g} / \mathrm{mL}$. Bruceine A has larvicidal activity against $A$. aegypti; therefore, it is a potential natural larvicide with low cytotoxicity.
\end{abstract}

Keywords: Bruceine A, Brucea javanica (L.) Merr, Larvicidal, Cytotoxicity, Aedes aegypti, Vero Cells

\section{Introduction}

Vector control is a measure to reduce the density of the vector mosquito population to such an extent that it loses the potential to transmit the disease. Earlier intervention studies showed that transmission could be reduced by giving temephos in high-risk areas. However, long-term use will lead to adaptation, evolution and selection of mosquitoes resistant to insecticides (Chen et al., 2001; Ponlawat et al., 2005). The World Health Organization (WHO) recognizes that the continuous use of chemical insecticides for a long period of time and with high frequency may result in decreased susceptibility of the mosquito target (WHO, 2009). Likewise, Sanchez et al. (2006) reported that the eradication of pests using chemical insecticides at fixed frequencies has resulted in side effects including resistance of the target pest and negative effects on nontarget organisms, such as natural predators and also causes environmental pollution. This situation requires research and development of vector control methods that are more environmentally friendly and less costly. One possible solution is the use of insecticides and larvicides derived from plants (Isman, 2006; 2015; 2017). Natural insecticides are relatively safe and more cost effective than chemical ones, because their residues are easily degraded and do not easily pollute the environment; however, this type of insecticide is less persistent in the environment. Natural insecticides have the potential for vector control because they are capable of killing larvae (Isman, 2006; 2013; Isman and Grieneisen, 2014).

Makassar Fruit (Brucea javanica L. Merr) plants belongs to the family Simaroubaceae, which is known for being rich in quassinoid compounds such as 
bruseantin, brusatol and bruceine (Takeya et al., 2006; Dong et al., 2013). So, far, 72 compounds have been identified from these plants, including 52 quassinoids, nine triterpenoids, five glycosides and one monoterpenoid (Liu et al., 2011). Bruceine A is isolated from the seeds and fruit of B. javanica (L.) Merr (Kim et al., 2004; Liu et al., 2012; Su et al., 2013; Ye et al., 2015; Du et al., 2017) and has the molecular formula $\mathrm{C}_{26} \mathrm{H}_{34} \mathrm{O}_{11}$, a mass of $522.54 \mathrm{~g} / \mathrm{mol}$ and a powder with bitter taste (NoorShahida et al., 2009; Liu et al., 2011). Bruceine A has insecticidal, antifeedant and growth inhibition activities against tobacco budworm (Heliothis virescens F), armyworm (Spodoptera frugiperda) (Klocke et al., 1985) and fourth instar larvae of Mexican beetles (Epilachna varivestis Mulsant)(Leskinen et al., 1984). Syahputra (2008) and Lina et al. (2013) proved that the active materials contained in extracts of $B$. javanica (L.) Merr have larvicidal effects against Crocidolomia pavonana. Extracts of $B$. javanica (L.) Merr can inhibit feeding, decrease the rate of growth and inhibit nesting of imago C. pavonana (Lina et al., 2013). Zhang et al. (2013) demonstrated that brusatol isolated from B. javanica (L.) Merr has insecticidal and antifeedant effects against third instar larvae of Spodoptera exigua. Sutiningsih and Nurjazuli (2017) proved that brusatol isolated from the seeds of B. javanica (L.) Merr has larvicidal activity against Aedes aegypti at $\mathrm{LC}_{50}$ and $\mathrm{LC}_{90}$ of $0.669 \pm 0.106 \mathrm{ppm}$ and $8.331 \pm 0.060 \mathrm{ppm}$, respectively. Therefore, further studies are required to examine the larvicidal activity of bruceine A on the larvae of Aedes aegypti (A. aegypti) and its cytotoxicity in normal cells (Vero cells). Cytotoxicity testing of bruceine A must be carried out to determine its level of toxicity against normal cells and thus, its safety when used as a larvicidal drug from natural materials.

\section{Material and Methods}

\section{Extraction and Isolation of Bruceine A}

Extraction and isolation of bruceine A was carried out at the Pharmaceutical Biology Laboratory, Faculty of Pharmacy, Gadjah Mada University. Brucea javanica (L.) Merr was purchased from a wholesaler of medicinal plants (Aneka Herbal Yogyakarta, Indonesia). The specimen was further identified in the Laboratory of Pharmaceutical Biology, Faculty of Pharmacy Gadjah Mada University, Yogyakarta, Indonesia to reconfirm the identity of the sample and to obtain relevant scientific information about it. Bruceine $\mathrm{A}$ isolation from B. javanica (L.) Merr seeds was undertaken based on the method described by Subeki et al. (2007). As many as 10 $\mathrm{kg}$ of Makassar Fruit of soaked under $30 \mathrm{~mL}$ of ethanol (EtOH) $70 \%$ for 28 days, then filtrated using filter clothe and steamed using rotary evaporator until it reaches $1 \mathrm{~L}$. Extract the thick filtrate using ethyl acetate (EtOAc), until water fraction and EtOAc are obtained. The EtOAc fraction are steamed until it dried and put inside silica gel of column chromatography and eluted with chloroform $(\mathrm{CHCl} 3)(1 \mathrm{~L}), \mathrm{MeOH}-\mathrm{CHCl} 3(3: 97,1 \mathrm{~L})$ and $\mathrm{MeOH}-$ $\mathrm{CHCl}_{3}$ (1:4, 1 L) respectively. Applying the same step, the drying is done inside the silica gel of column chromatography and eluted with hexane: EtOAc (3:7, 4 L) until 10 fractions are obtained. From the crystallization of fifth fraction using methanol $(\mathrm{MeOH})$ solvent, bruceine A compound is obtained and analysis is conducted using High-Performance Liquid Chromatography (HPLC). All commercial reagents and other chemicals used in this study purchased from commercial suppliers and were of analytical quality with the highest purity available.

\section{Larvicidal Activity Test of Bruceine A}

A larvicidal activity test was conducted using a bioassay according to the standards of the WHO (2005) with a slight modification. The third instar larvae of $A$. aegypti up to the beginning of instar IV were acquired and allowed to develop at the Laboratory of Parasitology, Faculty of Medicine, University of Gadjah Mada. A preliminary test was conducted to determine the range of concentrations of bruceine $A$ that could be deadly to larva of $A$. aegypti from instar III until the beginning of instar IV. In further tests, temephos was used as a positive control at a concentration of $1 \mathrm{ppm}$, whereas the negative control consisted of $100 \mathrm{~mL}$ of distilled water only. The selection of temephos dosage (1 ppm) was based on lethal damage consideration used in the field. Larvae of $A$. aegypti from the end of instar III to the beginning of instar IV were used and 25 larvae were used in each treatment medium and control, replicated three times. After $24 \mathrm{~h}$, the dead larvae of $A$. aegypti were counted. The temperature and $\mathrm{pH}$ of the media and humidity in the room were measured at the beginning and the end of the study.

\section{Bruceine A Cytotoxicity Test}

The bruceine A cytotoxicity test in Vero cells was conducted using the Micro-culture Tetrazolium assay (MTT) (Von Meerloo et al., 2011) with minor modifications. Vero cells were cultured using M199 medium supplemented with $10 \%$ FBS, $2 \%$ penicillinstreptomycin and $0.5-1 \%$ fungizone. Vero cells were removed from liquid nitrogen and warmed at $37^{\circ} \mathrm{C}$ until thawed. The thawed cell suspension was place in a conical tube and washed with M199 complete medium. The cell suspension was then transferred to a culture flask and incubated in a $37^{\circ} \mathrm{C}$ incubator with $5 \% \mathrm{CO}_{2}$. Vero cell growth was observed by inverted microscopy every day until the cells neared $100 \%$ confluence, at which time the cells were harvested. Cells were washed with PBS and $0.25 \%$ trypsin was added to detach the cells from the flask bottom. The cells were suspended in complete medium and counted in a hemocytometer. Cells were seeded in 
96-well microplate at a density of $2 \times 10^{4}$ cells/well in 100 $\mu \mathrm{L}$. Culture medium containing bruceine $\mathrm{A}$ at various concentrations $(1000,500,250,125,62.5$ and 31.25 $\mu \mathrm{g} / \mathrm{mL}$ ) was added. Cell cultures were incubated for $24 \mathrm{~h}$ in an incubator at $37^{\circ} \mathrm{C}$ in $5 \% \mathrm{CO}_{2}$. Cell growth was observed using MTT and treated cultures were compared with the untreated control culture. The medium was discarded after the incubation period and $100 \mu \mathrm{L}$ of complete medium and $10 \mu \mathrm{L}$ of MTT solution were added. The assay was incubated for $4 \mathrm{~h}$ in an incubator at $37^{\circ} \mathrm{C}$ and $5 \% \mathrm{CO}_{2}$. Then, $100 \mu \mathrm{L}$ of $10 \%$ SDS in $0.01 \mathrm{M}$ $\mathrm{HCl}$ was added to dissolve the formazan and incubated overnight at room temperature. The test result was read in an ELISA reader at a wavelength of $595 \mathrm{~nm}$.

\section{Data Analysis}

The percentages of larval mortality and viable Vero cells were expressed as mean \pm Standard Error of the Mean (SEM). The ratio of $\mathrm{LC}_{50} / \mathrm{LC}_{90}$ of bruceine $\mathrm{A}$ on $A$. aegypti larvae was calculated using probit regression analysis using SPSS version 24. Vero cell viability after bruceine A treatment at each concentration was expressed as $\mathrm{IC}_{50}$ and analyzed by regression (Sutejo et al., 2016). Statistical analysis were performed using one-way ANOVA if the data were normally distributed and homogeneous; otherwise, the Kruskal-Wallis test was used. Statistically significant differences were indicated by $\mathrm{p}<0.05$.

\section{Results}

\section{Isolation of Bruceine A from B. javanica (L.) Merr}

Using the extraction and isolation method of Subeki et al. (2007), as much as $100 \mathrm{mg}$ of isolated bruceine A compound was obtained from each $10 \mathrm{~kg}$ of $B$. javanica (L.) Merr. The purity levels of the amorphous powder were measured using two-dimensional chromatography with a stationary phase of silica gel 60 F254 on a TLC plate and a mobile phase of a mixed solvent of chloroform and ethyl acetate in a ratio of 1: 2 to produce a single purple spot observed under UV light at $366 \mathrm{~nm}$ with an Retardation factor (Rf) value of 0.88 . The result of calculation based on the area under the graph of high performance liquid chromatography of bruceine A isolates showed the presence of compounds with as much as $92.976 \%$ purity and a Retention time (Rt) of $4.633 \mathrm{~min}$.

\section{Larvicidal Activity of Bruceine A}

The environment considered in this study was the $\mathrm{pH}$ of the media, media temperature and humidity. These were measured at the beginning and end of the study as $\mathrm{pH} 7,25^{\circ} \mathrm{C}$ and $70-71 \%$, respectively. The larvicidal activity test of bruceine $\mathrm{A}$ on A.aegypti larvae was performed in triplicate. The average percentage mortality of $A$. aegypti larvae after $24 \mathrm{~h}$ of observation is presented in Table 1. The highest average lethality in A. aegypti larvae $(99.33 \%)$ was achieved at a bruceine A concentration of $16 \mathrm{ppm}$, whereas at the lowest concentration of bruceine A $0.25 \mathrm{ppm}$, the percentage lethality was $34.33 \%$. The toxicity of bruceine A on $A$. aegypti larvae was reflected in the $\mathrm{LC}_{50}$ and $\mathrm{LC}_{90}$, which were determined by probit analysis using SPSS version 24. The average values of $\mathrm{LC}_{50}$ and $\mathrm{LC}_{90}$ of bruceine $\mathrm{A}$ against larvae of $A$. aegypti in the three larvicidal tests were $0.453 \mathrm{ppm}$ and $4.962 \mathrm{ppm}$ (Table 2). Results of the Kolmogorov-Smirnov test for normality showed that the average mortality of $A$. aegypti larvae was normally distributed $(p=0.137)$, while the results of the test for homogeneity showed that the average number of deaths of A. aegypti larvae was homogeneous ( $\mathrm{p}=0.086$ ); therefore, to test for differences in the average number of deaths of $A$. aegypti larvae, one-way ANOVA was used.

Table 1: The average of percent mortality of $A$. aegypti larvae in the group treated with bruceine A in a wide range of concentrations, temephos at a concentration of $1 \mathrm{ppm}$ and control after $24 \mathrm{~h}$ of observation

\begin{tabular}{|c|c|c|c|c|c|}
\hline Bruceine A concentration (ppm) & No. of larvae & \multicolumn{3}{|c|}{ Mortality of $A$. aegypti on each test (\%) } & Mean \pm SEM $(\%)$ \\
\hline 0.25 & 25 & 38 & 36 & 29 & $34.33 \pm 1.42 *$ \\
\hline 0.5 & 25 & 59 & 53 & 59 & $57.00 \pm 1.04 *$ \\
\hline 1 & 25 & 68 & 58 & 83 & $69.67 \pm 3.79 *$ \\
\hline 2 & 25 & 79 & 72 & 84 & $78.33 \pm 1.82 *$ \\
\hline 4 & 25 & 84 & 82 & 90 & $85.33 \pm 1.26^{*}$ \\
\hline 8 & 25 & 92 & 93 & 97 & $94.00 \pm 0.80 *$ \\
\hline 16 & 25 & 100 & 98 & 100 & $99.33 \pm 0.35 *$ \\
\hline Temephos 1 ppm & 25 & 100 & 100 & 100 & $100 \pm 0.00$ \\
\hline Control & 25 & 0 & 0 & 0 & $0 \pm 0.00$ \\
\hline
\end{tabular}

${ }^{*} \mathrm{p}<0.05$ with one-way ANOVA test, SEM: Standard Error of the Mean, ppm: part per million

Table 2: The average of value of Lethal Concentration 50 and $90\left(\mathrm{LC}_{50}\right.$ and $\left.\mathrm{LC}_{90}\right)$ of bruceine $\mathrm{A}$ on $A$. aegypti larvae in each test

\begin{tabular}{|c|c|c|c|c|}
\hline Value of LC & \multicolumn{3}{|c|}{ Concentration of bruceine $\mathrm{A}(\mathrm{ppm})$ on each test } & Mean \pm SEM $(\mathrm{ppm})$ \\
\hline 50 & 0.408 & 0.535 & 0.415 & $0.453 \pm 0,022$ \\
\hline 90 & 4.923 & 7.240 & 2.724 & $4.962 \pm 0,681$ \\
\hline
\end{tabular}

SEM: Standard Error of the Mean, LC: Lethal Concentration, ppm: part per million 

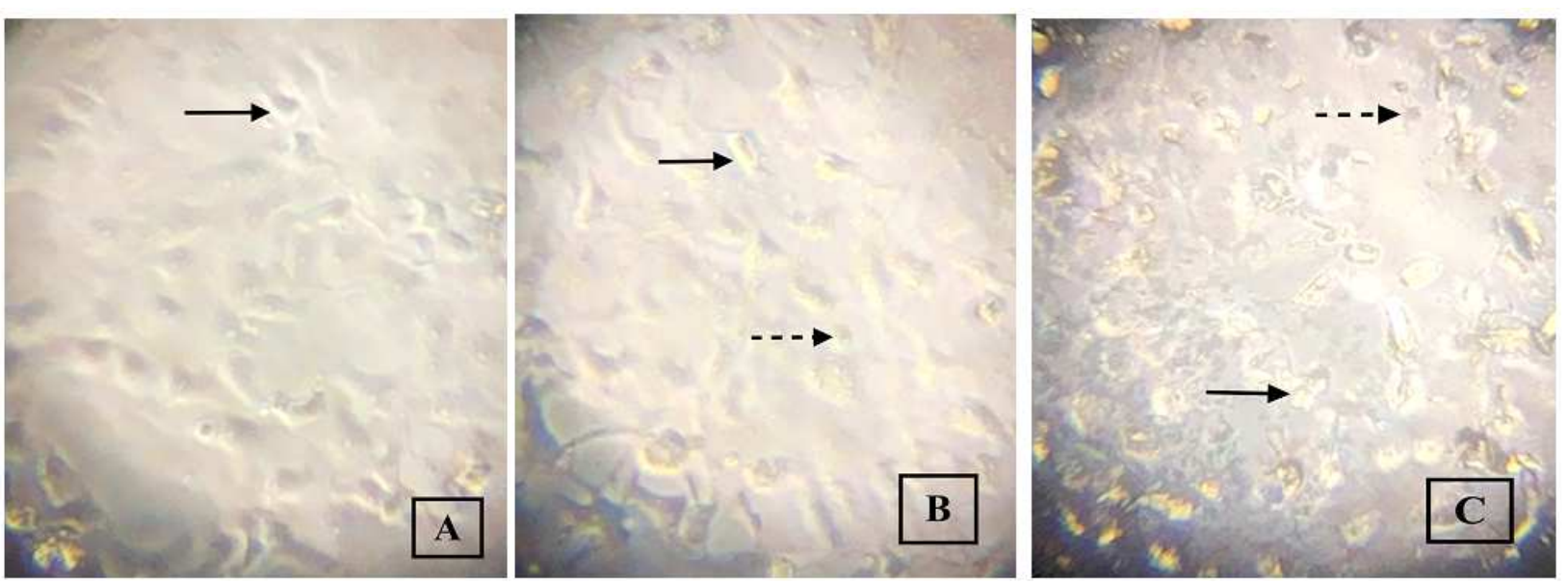

Fig. 1: Morphology of Vero cell controls (untreated) and cells treated with bruceine A (400x). A. Vero cells control, B. Vero cells treated $31.25 \mu \mathrm{g} / \mathrm{mL}$, C. Vero cells treated $1000 \mu \mathrm{g} / \mathrm{mL} ;(\longrightarrow$ : viable cells; $\cdots \cdots$ : non viable cells)

Table 3: The average number of live Vero cells and the percentage of viable cells after bruceine A administration and in the control

\begin{tabular}{|c|c|c|c|c|c|c|}
\hline \multirow[b]{2}{*}{$\begin{array}{l}\text { Bruceine A } \\
\text { conc. }(\mu \mathrm{g} / \mathrm{mL})\end{array}$} & \multicolumn{5}{|c|}{ Replication } & \multirow[b]{2}{*}{$\begin{array}{l}\text { Viable cell } \\
\pm \text { SEM }(\%)\end{array}$} \\
\hline & ----- & II & III & IV & Mean & \\
\hline 1000 & 0.24 & 0.33 & 0.36 & 0.71 & 0.41 & $51.88 \pm 0.06$ \\
\hline 500 & 0.68 & 0.34 & 0.65 & 0.74 & 0.60 & $77.90 \pm 0.05$ \\
\hline 250 & 0.68 & 0.79 & 0.44 & 0.71 & 0.65 & $85.27 \pm 0.05$ \\
\hline 125 & 0.63 & 0.84 & 0.79 & 0.44 & 0.67 & $87.85 \pm 0.05$ \\
\hline 62.5 & 0.74 & 0.84 & 0.77 & 0.61 & 0.74 & $97.14 \pm 0.03$ \\
\hline 31.25 & 0.73 & 0.75 & 0.83 & 0.73 & 0.76 & $99.79 \pm 0.01$ \\
\hline Cell control & 0.71 & 0.76 & 0.77 & 0.81 & 0.76 & $100 \pm 0.01$ \\
\hline Media control & 0.04 & 0.03 & 0.03 & 0.03 & 0.03 & $0 \pm 0.00$ \\
\hline
\end{tabular}

SEM: Standard Error of the Mean

\section{Bruceine A Cytotoxicity on Vero Cell}

The average number of live Vero cells observed and the percentage of viable cells after exposure to bruceine $\mathrm{A}$ and in the control can be seen in Table 3. Figure 1 shows the morphology of Vero cells in the control and after treatment with bruceine A observed by microscopy. On the morphological profile of control Vero cells (Fig. 1A), there are no mortality compared with bruceine A treatment at concentrations of 31.25 $\mu \mathrm{g} / \mathrm{mL}$ (Fig. 1B) and $1000 \mu \mathrm{g} / \mathrm{mL}$ (Fig. 1C). The survived (viable) Vero cells look bright because of the cytoplasm liquid that transmit the light from inverted microscope. On the other hand, Vero cells that are dead after treatment with bruceine A look blackish (dark), shrinked and rounded because the cells lost the cytoplasm liquid in accordance with the damage on cell membranes.

The percentage of viable Vero cells reached $99.79 \pm 0.01 \%$ at the lowest concentration of bruceine A $(31.25 \mu \mathrm{g} / \mathrm{mL})$, whereas at the highest concentration $(1000 \mu \mathrm{g} / \mathrm{mL})$, the percentage of viable cells was $51.88 \pm 0.06 \%$. Results of probit analysis using SPSS version 24 obtained an $\mathrm{IC}_{50}$ value of bruceine $\mathrm{A}$ in Vero cells of $1251.32 \pm 0.16 \mu \mathrm{g} / \mathrm{mL}$. The Kolmogorov-
Smirnov test results showed that Vero cell viability was normally distributed $(p=0.119)$, while the homogeneity test results showed that Vero cell viability in the different groups did not have the same variance $(p=$ 0.001 ); therefore, to test for differences in average Vero cell variability at various concentrations of bruceine A, a Kruskal-Wallis test was performed. The results of this test showed no difference in the average percentage of viable Vero cells at various concentrations of bruceine A $(p=0.153)$.

\section{Discussion}

\section{Larvicidal Activity of Bruceine A againts A. aegypti}

The A. aegypti larvae used in this study are of instar III until early instar IV. Larvae of instar III and IV already have perfectly shaped organs, so death after treatment could not be attributed to the organs not being fully formed. The $\mathrm{pH}$ and temperature of the media and humidity of the environment at the time of the study were $7,25^{\circ} \mathrm{C}$ and $70-71 \%$. The levels of $\mathrm{pH}$, temperature and room humidity in the media were still within the optimal $\mathrm{pH}$ range $(6.5-7)$, temperature $\left(25-27^{\circ} \mathrm{C}\right)$ and air 
humidity $(60-80 \%)$ for the development of $A$. aegypti larvae in bioassay research (WHO, 2005). Therefore, it can be concluded that the $\mathrm{pH}$, temperature and humidity of the media at the time of the study did not interfere with the development of $A$. aegypti larvae. The death of $A$. aegypti larvae was not caused by these environmental factors. The growth and development of larvae were influenced by the adequacy of food sources, the temperature and the presence or absence of predators (Dharmagadda et al., 2005).

Larval mortality of $A$. aegypti was observed after 24 $\mathrm{h}$, based on the provisions of the Commission on Pesticides (Pesticide Committee, 1995), which states that a larvicide is said to be effective if the percentage of dead larvae reaches at least $90 \%$ within $24 \mathrm{~h}$. The results of a $24 \mathrm{~h}$ observation showed no larval mortality in the control group; therefore, the number of dead larvae of $A$. aegypti in the treatment group did not require correction by the Abbott's formula (Abbott, 1987). The percentage of dead larvae of $A$. aegypti was more than $90 \%$ after a $24 \mathrm{~h}$ observation with bruceine $\mathrm{A}$ at a concentration of $8 \mathrm{ppm}$ (Table 1). The higher the concentration of bruceine A applied, the higher the average percentage of death of $A$. aegypti larvae observed. This means that bruceine $\mathrm{A}$ is effective as a natural larvicide on the larvae of $A$. aegypti, which is in accordance with the provisions of the Pesticide Committee (1995). According to Sharma et al. (2015), the interaction of toxic substances in a biological system is determined by the concentration and duration of the test. One-way ANOVA test results showed that the average number of deaths of $A$. aegypti larvae at various concentrations of bruceine A was significantly different $(p<0.05)$. Differences in larval mortality of $A$. aegypti are likely to be influenced by several factors, namely the instar stage of the larvae and differences in the sensitivity of each test larva. The differences in instar stage of the larvae are influenced by the age of each test larva. Although we used larvae of instar III to early instar IV, there was still variation in the age of larvae. Early instar III larvae are more susceptible to insecticides than early instar IV larvae. In addition, differences in larval mortality are influenced by differences in the sensitivity of each test larvae. Even when larvae with the same instar and age are used, each larva has a different level of vulnerability (Paulraj et al., 2011).

The death of $A$. aegypti larvae in the current study was due to the toxic activity of bruceine A compound. The toxicity of bruceine A to A. aegypti larvae reflected by the $\mathrm{LC}_{50}$ and $\mathrm{LC}_{90}$ were $0.453 \pm 0.022 \mathrm{ppm}$ and $4.962 \pm 0.681 \mathrm{ppm}$. Meanwhile, studies by Sutiningsih and Nurjazuli (2017) reported values of $\mathrm{LC}_{50}$ and $\mathrm{LC}_{90}$ for brusatol on larvae of $A$. aegypti of $0.669 \pm 0.106 \mathrm{ppm}$ and $8.331 \pm 0.060 \mathrm{ppm}$, respectively. The smaller the value of lethal concentration, the more toxic the compound (Paulraj et al., 2011). This means that bruceine A isolated from the Makassar Fruit ( $B$. javanica L. Merr) is more toxic than brusatol in $A$. aegypti larvae. Bruceine $\mathrm{A}$ is one of quassinoids that is isolated from the seeds of B. javanica (L.) Merr (Bawn et al., 2008). As seen from the structure, bruceine A consists of five fused rings containing a heterocyclic oxygen ring and a methylenedioxy bridge on ring $\mathrm{C}$ and lactone rings in ring $\mathrm{D}$, demonstrating that bruceine $\mathrm{A}$ has larvicide/insecticide and antifeedant activities. According to Feng et al. (2010) a partial structure of a compound has antifeedant and insecticidal activity if it has a carbonyl group on ring $\mathrm{A}$; an $\alpha, \beta$ unsaturated carbonyl or a methylenedioxy bridge on ring $C$; and a $\theta$-lactone group on ring $D$.

Bruceine A was also shown to have insecticidal activity and antifeedant and growth inhibitory effects against Heliothis virescens and Spodoptera frugiperda and strong antifeedant activity on instar III larvae of migratory Locusta migratorioides and instar IV larvae of the Mexican bean beetle (Epilachna varivestis Mulsant) (Bhattacharjee et al., 2009). Bruceine A enters the larvae body through the mouth of larvae (eaten by larvae). These compounds are expected to decrease the activity of the protease enzyme and the absorption of food and inhibit the taste receptors in the mouth, which will lead to the larvae failing to perceive a taste stimulus, so that the larvae cannot recognize food in its surroundings (Chaithong et al., 2006). The low feeding activity of the larvae reduces their energy so that the growth process is also hampered and they eventually die. In addition, the bitter taste of the bruceine A compound also acts to inhibit eating in larvae. The bitter taste causes the larvae to not want to eat, so the larvae starve and eventually die. The toxic compounds of bruceine A consumed by larvae will affect the amount and rate of eating, resulting in reduced growth and survival. Some of the energy consumed in food is used for detoxification of toxic compounds (Sharma et al., 2015). Sublethal dosage of bruceine A can inhibit the growth and development of A. aegypti larvae by promoting damage to the gastrointestinal tract/midgut and cuticles as well as necrosis of the gastrointestinal epithelial cells in the midgut (Sutiningsih et al., 2017).

Sanjaya and Safaria (2006) explained that the toxic compounds that enter the body can cause a four-stage response in larvae: Excitation, convulsions, paralysis and death. The toxic compounds of bruceine A will affect and disrupt the physiological system, causing the larvae of $A$. aegypti to die. Bruceine $\mathrm{A}$ is a toxic substance that can kill larvae of $A$. aegypti, entering the body of larvae through the pores of the skin, gastrointestinal tract and respiratory tract/siphon. Toxic compounds cause disruption of the digestive, respiratory and nervous systems of larvae (Choochote et al., 2004; Dharmagadda et al., 2005; 
Chaithong et al., 2006; Warikoo and Kumar, 2013). Bruceine $\mathrm{A}$ is suspected to enter through the larval skin membrane by diffusion facilitated by a carrier protein such as hemoglobin ( $\mathrm{Lu}$ and Kacew, 2002). The number of toxic compounds that enter causes damage to skin cells. This toxic compound hydrolyzes the skin cell membrane by breaking down the skin protein (collagen) into several parts (Krieger, 2010). The destruction of skin cell membranes causes loss of the impermeable barrier of the skin, so other toxic compounds are free to enter the body of the larvae. The large number of toxic compounds that enter cause the protein in the skin membranes to be damaged, so that the function of the skin as a body protector is disturbed (Lu and Kacew, 2002).

In addition, bruceine $\mathrm{A}$ is estimated to enter through the digestive tract. The gastrointestinal tract of mosquito larvae consists of three parts, namely the digestive tract at the front, middle and back. The process of digestion and absorption of food occurs in the central gastrointestinal tract (Farnesi et al., 2012). The middle digestive tract is coated with epithelial tissue. Toxic substances enter through the mouth of the larvae and continue into the midgut/middle digestive tract. This toxic substance causes epithelial cells to undergo lysis resulting in a decrease in stress on the surface of the membrane coat of the central gastrointestinal tract so that digestion and absorption of food do not occur (Lu and Kacew, 2002).

Another suspected way bruceine A enters the larval body is through the respiratory tract. Air enters through a siphon affixed to the water surface. This toxic substance is thought to cover the surface of the medium, thus blocking the siphon from obtaining oxygen from the surface of the medium (Lu and Kacew, 2002). Neural tissues of the larvae are very sensitive to a lack of oxygen, which causes wilting of the nerves and damage to siphon so that the larvae have difficulty breathing and eventually die (Krieger, 2010).

\section{Bruceine A Cytotoxicity on Vero Cell}

The cytotoxic effect of bruceine A on Vero cell lines was evaluated through the Micro-culture Tetrazolium assay (MTT). The MTT reagent is reduced to formazan salts by the succinate dehydrogenase enzyme present in the mitochondria of living cells. The formazan salts formed are measured as absorbance. The higher the absorbance, the more cells are alive (high cell viability) (Mahto et al., 2010). The result of statistical analysis using the Kruskal-Wallis test showed that there was no difference in the percentage of viable Vero cells at various concentrations of bruceine $A(p>0.05)$. At low concentrations of bruceine A, Vero cell viability was higher (Table 3). The results of this study showed that bruceine A affects the viability of Vero cells. Vero cells are normal polygonal and flat monolayer cells isolated from kidney cells of African green monkey by Yasumura and Kawakita at Chiba University, Japan (Yasumura and Kawakita, 1963). This cell is a type of immortal, nontumorigenic fibroblast (Goncalves et al., 2006). Vero cells attach very strongly to polystyrene-based substrates by forming covalent bonds. These cells are homologous to human body cells and are easily cultured. A healthy Vero cell is triangular and will take on a "rounded-off" shape when interacting with a compound with cytotoxic activity (Liao et al., 2010). The potential for bruceine A cytotoxicity can be seen from the $\mathrm{IC}_{50}$. The value of $\mathrm{IC}_{50}$ of bruceine A against Vero cells is $1251.32 \pm 0.16$ $\mu \mathrm{g} / \mathrm{mL}$. The results of test seem to indicate that bruceine $\mathrm{A}$ is not toxic to Vero cells because it has an $\mathrm{IC}_{50}$ value $>100 \mu \mathrm{g} / \mathrm{mL}$ (Vijayarathna and Sasidharan, 2012) The $\mathrm{IC}_{50}$ value obtained from this research is lower than the value of $\mathrm{IC}_{50}$ reported by Mangungsong (2012) $(1366.55 \pm 53.43 \mu \mathrm{g} / \mathrm{mL})$ and the $\mathrm{IC}_{50}$ of brusatol on Vero cells $(14.03 \pm 0.16 \mu \mathrm{g} / \mathrm{mL}$ ) (Sutiningsih and Nurjazuli, 2017). However, the $\mathrm{IC}_{50}$ value of bruceine $\mathrm{A}$ in Vero cells is higher than the $\mathrm{IC}_{50}$ of ethanol extract of Makassar Fruit $(395.5 \pm 4.21 \mu \mathrm{g} / \mathrm{mL})($ Sutejo et al., 2016). The higher value of $\mathrm{IC}_{50}$ against Vero cells means the compounds are less toxic to normal cells (Badisa et al., 2011). This means that bruceine $A$ and brusatol, which are active isolates of the Makassar Fruit seeds, have lower toxicity to normal cells than Makassar Fruit extract. The differences in $\mathrm{IC}_{50}$ value may have been due to the different characteristics of the test cells used at the time of the study. In addition, the active substances contained in Makassar Fruit, such as bruceine A and brusatol, are thought to play an active role in the cytotoxicity of Vero cells. Treatment with bruceine A at various concentrations causes morphological changes in Vero cells (Fig. 1). Bruceine $\mathrm{A}$ at a concentration of $1000 \mu \mathrm{g} / \mathrm{mL}$ causes many changes in the morphology of Vero cells compared with a concentration of $31.25 \mu \mathrm{g} / \mathrm{mL}$. Morphological changes of Vero cells expected to be the result from the protein that has a role on cells attachment did not polimerate so the cells detached dan lipid membrane became rounded and cytoskeleton were cut (Prayong et al., 2008). The decrease on cells viability and density appeared on higher dosage used, along with the morphological changes that was shrinking which was indication of mortified cells (Mathivadani et al., 2007; Sasayama et al., 2007). Morphological changes in Vero cells are characterized by physical changes such as the size and shape of the cell becoming smaller and rounder (Sutejo et al., 2016). Changes in cellular morphology can be caused by the mechanism of apoptosis in cells. Vero cells treated with bruceine A are suspected to undergo apoptosis resulting in morphological changes in the cells. Cellular morphological changes due to the mechanism of apoptosis can occur through several 
stages, such as the shrinking of cell density, condensation and fragmentation of cell chromatin and cell nucleus fragmentation (Elmore, 2007). Bruceine A seems to be effective as a natural larvicide against $A$. aegypti and has a low cytotoxic effect on Vero cells. The limitation of this research is bruciene A from the seeds of Makassar Fruit (B. javanica L. Merr) only performed by examining the larvacide on $A$.aegypti larvae and its in vitro toxicity. It is necessary to conduct further research on potentials of bruceine $\mathrm{A}$ as natural larvicide and insecticide on other species of mosquitoes, formulation of larvicide or insecticide preparation from bruceine A and the toxicity of bruceine A by in vivo.

\section{Conclusion}

Bruceine A isolated from seeds of the Makassar Fruit (B. javanica L. Merr) has the potential to be developed as a natural larvicide for the control of disease vectors, especially $A$. aegypti. Bruceine A seems to be effective and safe in normal cells (Vero cells).

\section{Acknowledgement}

We are deeply grateful to Sitarina Widyarini, Ph.D, Sugiyono, MSc and Rr. Upik Ngesti WA, MBiomed from University of Gadjah Mada who has helped in the reading of morphological preparations in this study.

\section{Author's Contributions}

Dwi Sutiningsih: Performed literature review, conducted experiments and wrote manuscript.

Mustofa: Reviewed the manuscript and participated in isolation of bruceine A.

Tri Baskoro Tunggul Satoto: Reviewed the manuscript and contributed to cytotoxic analysis.

Edhi Martono: Participated in data analysis and manuscript writing.

\section{Ethics}

This article is original and has not been published or presented elsewhere. All the authors have approved the manuscript and agree with submission to this journal.

\section{References}

Abbott, W.S., 1987. A method of computing the effectiveness of an insecticide. 1925. J. Am. Mosq. Control. Assoc., 3: 302-303. PMID: 3333059

Badisa, R., S. Darling-Reed, P. Joseph, J. Cooperwood and L. Latinwo et al., 2011. Selective cytotoxic activities of two novel synthetic drugs on human breast carcinoma MCF-7 cells. Anticancer Res., 29: 2993-2996. PMID: 19661306
Bawn, S., H. Matsuura, A. Elkhateeb, K. Nabeta and Subeki et al., 2008. In vitro antitrypanosomal activities of quassinoid compounds from the fruits of a medicinal plant, Brucea javanica. Vet. Parasitol., 158: 288-294.

DOI: 10.1016/j.vetpar.2008.09.021

Bhattacharjee, S., G. Gupta, P. Bhattacharya, A. Mukherjee and S. Mujumbar et al., 2009. Quassin alters the immunological patterns of murine macrophages through generation of nitric oxide to exert antileishmanial activity. J. Antimicrob. Chemother, 63: 317-324. DOI:10.1093/jac/dkn479

Chaithong, U., W. Choochote, K. Kamsuk, A. Jitpandi, and P. Tippawangkosol et al., 2006. Larvicidal effect of pepper plants on Aedes aegypti (L.) (Diptera: Culicidae). J. Vector Ecol, 31: 138-144. PMID: 16859102

Chen, Z.Z., R. Newcomb, E. Forbes, J. McKenzie and P. Batterham, 2001. The acetylcholinesterase gene and organophosphorus resistance in the Australian sheep blowfly, Lucilia cuprina. Insect. Biochem. Mol. Biol., 31: 805-816.

DOI: $10.1016 / \mathrm{S} 0965-1748(00) 00186-7$

Choochote, W., B. Tuetun, D. Kanjanapothi, E. Rattanachanpichai and U. Chaitong et al., 2004. Potential of crude seed extract of celery, Apium graveolens L., against the mosquito Aedes aegypti (L.) (Diptera: Culicidae). J. Vec. Ecol., 29: 340-346. PMID: 15707293

Dharmagadda, V., S. Naik, P. Mittal and P. Vasudevan, 2005. Larvicidal activity of Tagetes patula essential oil against three mosquito species. Biores. Tech., 96: 1235-1240. DOI: 10.1016/j.biortech.2004.10.020

Dong, S.H., J. Liu, Y.Z. Ge, L. Dong and C.H. Xu, et al., 2013. Chemical constituents from Brucea javanica. Phytochemistry, 85: 175-184.

DOI: 10.1016/j.phytochem.2012.08.018

Du, Y., Z. Cheng, P. Zhao, X. Huang and S. Song, 2017. Research review on the main chemical components of Brucea javanica (L.) Merr. Asian. J. Tradit. Med., 12: 240-249.

Elmore, S., 2007. Apoptosis: A review of programmed cell death. Toxicol. Pathol., 35: 495-516. DOI: $10.1080 / 01926230701320337$

Farnesi, L.C., J.M. Brito and G.L. Rezende, 2012. Physiological and morphological aspect of Aedes aegypti developing larvae: Effects of the chitin synthesis inhibitor novaluron. PloS One, 7: 1-23. DOI: 10.1371/journal.pone.0030363

Feng, X., Y. Zhang, W. He, L. Zhang and H. Jiang, 2010. Bruceine A. Acta. Crystallogr, 66: 854-855. DOI: $10.1107 / \mathrm{S} 1600536810007646$ 
Goncalves, E., C. Ventura, T. Yano, M. Macedo and S. Ganeri, 2006. Morphological and growth alterations in Vero cells transformed by cysplatin. Cell. Biol., 30: 485-494. DOI: 10.1016/j.cellbi.2005.12.007

Isman, M., 2006. Botanical insecticides, deterrents and repellents in modern agriculture and an increasingly regulated world. Annu. Rev. Entomol., 51: 45-66. DOI: 10.1146/annurev.ento.51.110104.151146

Isman, M.B., 2013. Botanical insecticides: A global perspective. Proceedings of the 246th National Meeting and Exposition, (NME' 13), American Chemical Society, Picogram, pp: 105-105.

Isman, M.B. and M.L. Grieneisen, 2014. Botanical insecticide research: Many publications, limited useful data. Trends Plant Sci., 19: 140-145. DOI: $10.1016 / \mathrm{j} . t$ plants.2013.11.005

Isman, M.B., 2015. A renaissance for botanical insecticides? Pest. Manage. Sci., 71: 1587-1590. DOI: $10.1002 / \mathrm{ps} .4088$

Isman, M.B., 2017. Bridging the gap: Moving botanical insecticides from the laboratory to the farm. Industrial Crops Products, 110: 10-14.

DOI: $10.1016 /$ j.indcrop.2017.07.012

Kim, I.H., Y. Hitotsuyanagi and K. Takeya, 2004. Quassinoid xylosides, javanicosides $\mathrm{G}$ and $\mathrm{H}$, from seeds of Brucea javanica. ChemInform, 35: 691-697. DOI: 10.1002/chin.200450181

Klocke, J., M. Arisawa, S. Handa, A. Kinghorn and I. Cordel et al., 1985. Growth inhibitory, insecticidal and antifeedant effects of some antileukemic and cytotoxic quassinoids on two species of agricultural pest. Experientia, 41: 379-382.

DOI: $10.1007 / \mathrm{BF} 02004516$

Krieger, R., 2010. Hayes' Handbook of Pesticide Toxicology. 3rd Edn., Academic Press, California, ISBN-10: 0080922015, pp: 2000.

Leskinen, V., J. Polonsky and S. Bhatnagar, 1984. Antifeedant activity of quassinoids. J. Chem. Ecol., 10:1497-507. DOI: 10.1007/BF00990319

Liao, T.T., Y.L. Shi, J.W. Jia and L. Wang, 2010. Sensitivity of different cytotoxic responses of Vero cells exposed to organic chemical pollutants and their reliability in the bio- toxicity test of trace chemical pollutants. Biomed. Environ. Sci., 23: 219-222. DOI: $10.1016 / \mathrm{S} 0895-3988(10) 60056-6$

Lina, E., Dadang, S. Manuwoto, G. Syahbirin and D. Prijono, 2013. Synergistic action of mixed extract Brucea javanica (Simaroubaceae), Piper aduncum (Piperaceae) and Tephrosia vogelli (Leguminosae) against cabbage head caterpillar, Crocidolomia pavonana. J. Biopestic., 6: 77-83.

Liu, J.Q., C.F. Wang, X.Y. Li, J.C. Chen and Y. Li et al., 2011. One new pregnane glycoside from the seeds of cultivated Brucea javanica. Arch. Pharm. Res., 34: 1297-1300. DOI: 10.1007/s12272-011-0809-5
Liu, J.H., N. Zhao, G.J. Zhang, S.S. Yu and L.J. Wu et al., 2012. Bioactive quassinoids from the seeds of Brucea javanica. J. Nat. Prod., 75: 683-688. DOI: $10.1021 / \mathrm{np} 200920 \mathrm{c}$

Lu, F. and S. Kacew, 2002. Lu's Basic Toxicology: Fundamentals, Target Organs and Risk Assessment. 4th Edn., 4th Ed., Taylor and Francis, New York. ISBN-10: 0415248566, pp: 392.

Mahto, S., P. Chandra and S. Rhee, 2010. In vitro models, endpoints and assessment methods for the measurement of cytotoxicity. Toxicol. Environ. Health. Sci., 2: 87-93. DOI: 10.1007/BF03216487

Mangungsong, S., 2012. The activity of semisynthetic quassinoid compound from Makasar Fruit (Brucea javanica L. Merr) as anticancer with target protein p53, bcl-2, kaspase-3, COX- 2 dan c-Myc. Unpublished dissertation in partial fulfillment of the requirements for the degree of Doctor of Philosophy, Gadjah Mada University, Yogyakarta, Indonesia.

Mathivadani, P., P. Shanthi and P. Sachdanandam, 2007. Apoptotic effect of Semecarpus anacardium nut extract on T47D cancer cell line. Cell. Biol. Int., 31: 1198-1206. DOI: 10.1016/j.cellbi.2007.04.004

NoorShahida, A., T.W. Wong and C.Y. Choo, 2009. Hypoglycemic effect of quassinoids from Brucea javanica (L.) Merr (Simaroubaceae) seeds. J. Ethnopharmacol., 124: 586-591.

DOI: $10.1016 /$ j.jep.2009.04.058

Paulraj, A., A. Reegan and S. Ignacimuthu, 2011. Toxicity of benzaldehyde and propionic acid against immature and adult stages of Aedes aegypti (Linn) and Culex quenquefasciatus (Say) (Diptera $\square$ : Culicidae). J. Entomol., 8: 539-547. DOI: 10.13057/biodiv/d070221

Pesticide Committee, 1995. Standard method of pesticidal effication assessment. Agriculture Department, Jakarta, Indonesia.

Ponlawat, A., J.G. Scott and L.C. Harrington, 2005. Insecticide susceptibility of Aedes aegypti and Aedes albopictus across Thailand. J. Med. Entomol., 42: 821-825. DOI: 10.1603/00222585(2005)042[0821:ISOAAA]2.0.CO;2

Prayong, P., S. Barusrux and N. Weerapreeyakul, 2008. Cytotoxic activity screening of some indigenous Thai plants. Fitoterapia, 79: 598-601. DOI: $10.1016 /$ j.fitote.2008.06.007

Sanchez, L., V. Vanlerberhe, L. Alfonso, M. Marqetti and M. Guzman et al., 2006. Aedes aegypti larval indices and risk for dengue epidemics. Emerg. Infect. $\quad$ Dis., 12 : 800-806. DOI:10.3201/eid1205.050866

Sanjaya, Y. and T. Safaria, 2006. Toxicity poison from spider Nephila sp to Aedes aegypti L. larvae. J. Biodiversitas, 7: 191-194. DOI: 10.13057/biodiv/d070221 
Sasayama, T., K. Tanaka, K. Mizukawa, A. Kawamura and T. Kondoh, et al., 2007. Trans-4-lodo, 4boranyl-chalcone induces antitumor activity against malignant cell lines in vitro and in vivo. $\mathrm{J}$. Neurooncol., 85: 123-132.

DOI: $10.1007 / \mathrm{s} 11060-007-9395-2$

Sharma, A., S. Kumar and P. Tripathi, 2015. Impact of Achyranthes aspera leaf and stem extracts on the survival, morphology and behaviour of an Indian strain of dengue vector, Aedes aegypti. J.M.R, 5: 1-9. DOI: 10.5376/jmr.2015.05.0007

Su, Z., J. Hao, Z. Xu, R. Huang and N. Zhang et al. 2013. A new quassinoid from fruits of Brucea javanica. Nat. Prod. Res., 27: 2016-2021. DOI: $10.1080 / 14786419.2013 .821119$

Subeki, H.M., K. Takahashi, K. Nabeta and M. Yamasaki, 2007. Screening of some Indonesian medicinal plants for antibabesial activity and isolation of new quassinoid fro Brucea javanica. J. Nat. Prod., 70: 1654-1657. DOI: $10.1021 / \mathrm{np} 070236 \mathrm{~h}$

Sutejo, I.R., H. Putri and E. Meiyanto, 2016. The selectivity of ethanolic extract of Makassar Fruit (Brucea javanica) on in vitro study of metastatic breast cancer. J. Agromed. Med. Sci., 2: 1-5. DOI: 10.19184/ams.v2i1.2422

Sutiningsih, D., Mustofa, T.B.T. Satoto and E. Martono, 2017. Inhibitory effects of bruceine A biolarvicide on growth and development of Aedes aegypti Larvae. J. Entomol., 14: 104-111.

DOI: $10.3923 /$ je.2017.104.111

Sutiningsih, D. and Nurjazuli, 2017. Effect of brusatol biolarvicide administration on behavioral response of Aedes aegypti and its toxicity on Vero cells. J. Biol. Sci., 17: 127-135.

DOI: $10.3923 /$ jbs.2017.127.135
Syahputra, E., 2008. Bioactivity of Brucea javanica fruit as nabatical insecticide for agricultural insect pest. Bul. Littro, 19: 56-67.

Takeya, K., I. Kim, Y. Hitotsuyanagi and T. Hasuda, 2006. Antitumour quassinoid from Brucea javanica and SAR of Brusatol. Planta. Med, 72: 20-24. DOI: $10.1055 / \mathrm{s}-2006-949920$

Vijayarathna, S. and S. Sasidharan, 2012. Cytotoxicity of methanol extracts of Elaeis guineensis on MCF-7 and Vero cell lines. Asian Pac J. Trop. Biomed, 2: 826-829. DOI: 10.1016/S2221-1691(12)60237-8

Von Meerloo, J., G. Kaspers and J. Cloos, 2011. Cell sensitivity assays: The MTT assay. Methods. Mol. Biol., 731: 237-245. DOI: $10.1007 / 978-1-61779-080-5 \_20$

Warikoo, R and S. Kumar, 2013. Impact of Argemone mexicana extracts on the cidal, morphological and behavioural response of dengue vector, Aedes aegypti L. (Diptera: Culicidae). Parasitol. Res., 112: 3477-3484. DOI: 10.1007/s00436-013-3528-7

WHO, 2009. Dengue: Guidelines for diagnosis, treatment, prevention and control new edition. WHO, France, ISBN-13: 978-92-4-154787-1.

WHO, 2005. Guidelines for laboratory and field testing of mosquito larvicides.

Yasumura, Y. and Y. Kawakita, 1963. Studies on SV40 in tissue culture-preliminary step for cancer research in vitro. Nippon Risnsho, 21: 1201-1215.

Ye, Q.M., L.L. Bai, S.Z. Hu, H.Y. Tian and L.J. Ruan et al. 2015. Isolation, chemotaxonomic significance and cytotoxic effects of quassinoids from Brucea javanica. Fitoterapia, 105: 66-72. DOI: 10.1016/j.fitote.2015.06.004

Zhang, L., X. Feng, D. Ma, J. Yang and H. Jiang et al., 2013. Brusatol isolated from Brucea javanica (L.) Merr induces apoptotic death of insect cell lines. Pestic. Biochem. Physiol., 107: 18-24. DOI: $10.1016 /$ j.pestbp.2013.04.007 